Word count: 7,031 words.

\title{
The impact of legitimacy pressure and corporate profitability on green innovation: Evidence from China top 100
}

\begin{abstract}
Green innovation is an important approach for achieving sustainable development. Most research on determinants of corporate green innovation has focused on either external or internal drivers. Combining institutional theory and resource-based view, the scientific value of this study lies in simultaneously exploring the influence of external legitimacy pressure and internal corporate profitability, and their interaction on green innovation. Samples of the top 100 listed companies in China, from 2008 to 2012, were used and the results demonstrated that legitimacy pressure from stakeholders has a significantly positive influence on both corporate green product innovation and process innovation. The results also revealed that corporate profitability positively affects green product innovation, while there was found to be no significant influence on green process innovation. Moreover, corporate profitability positively moderates the relationship between legitimacy pressure and green product innovation. The results show that not only the single factor of external legitimacy pressure and internal profitability, but also their interaction, affects corporate green innovation practices. This offers an integrating perspective on how corporations can be more innovative in sustainability.
\end{abstract}

Keywords: legitimacy pressure; corporate profitability; green innovation; green product innovation; green process innovation; China

\section{Introduction}

The world has witnessed extreme environmental deterioration over the last few decades and in China, the extensive-growth mode has resulted in severe environmental pollution and ecological devastation, which has overwhelmingly 
affected people's normal lives. Firms are widely regarded as the main cause of environmental problems and are facing tremendous pressure of environmental legitimacy from various stakeholders (Bansal and Clelland, 2004). Pressure from the media, consumers and other stakeholders pushes corporations to adopt innovative measures to improve their environmental performance. Green innovation lays a foundation for a firm to balance profitability and environmental responsibility whilst at the same time achieving an economic-social-environmentally harmonious development model, which has been extensively advocated by researchers and practitioners.

Green innovation refers to the generation of new ideas, goods, services, processes, or management systems that can be used to cope with environmental problems (Rennings, 2000). Green innovation can effectively reduce environmental pollution and the negative impacts of resource (and energy) use processes, and thus can create sustainable development (Kemp and Pearson, 2007). Lai et al. (2003) found that green innovation can contribute to environmental performance by meeting stakeholders' environmental requirements. In this way, green innovation is not only an important way for enterprises to gain a competitive advantage in the future, but also it will become the basic requirement to obtain legitimacy.

Research of corporate green innovation is mainly concentrated in two specific aspects. The first is that research focuses on the driving factors of green innovation, including stakeholder pressures, government regulations, redundant resources, expected economic benefits and environmental consciousness of managers and employees (Caputo, 2014; Delgado - Ceballos et al, 2012; Murillo - Luna, 2008). The other aspect of the research focuses on the consequences of green innovation; i.e., the relationship or mechanism between green innovation and corporate performance (Amores-Salvadó et al., 2014; Eiadat et al., 2008). Even though there is no unanimous conclusion at present, existing empirical studies show the positive role of corporate green innovation on business performance calls for configurable conditions 
(Horvathova, 2012; Sarkis and Cordeiro, 2001). The academic interest in green innovation is increasing but few studies have explored its driving forces by integrating external and internal factors (Lozano, 2015), and seldom any combine a legitimacy perspective with a resource-based view (Berrone, et al., 2013; De Marchi, 2012).

Legitimacy, a core concept of institutional theory, is defined from various perspectives, among which Suchman's (1995) definition is widely accepted: legitimacy refers to the state where "the actions of an entity are appropriate within some socially constructed system of norms, values, beliefs, and definitions" (p. 574). Such systems can be explicit or implicit, so it is not enough for firms to just obtain the legal requirements or market demands, but they should also be consistent with the prevailing norms and values of the society (Alrazi, Villiers and Staden, 2015). Stakeholders often assess an entity's legitimacy level according to their own perceptions, and these stakeholders usually include investors, customers, the community, the public and regulators (Bansal and Clelland, 2004). Lack of legitimacy will result in negative cognitions and actions of various stakeholders. When a company engages in environmental violations such as water contamination, investors may sell off its stocks, creditors may impose higher interest rates, consumers may refuse to purchase its products or services, the government may increase sewage charges or even compel it to stop operation, and the public may engage in the media to create legitimacy pressure on the firm (Alrazi et al., 2015), which will put the firm at great risk (Bansal and Clelland, 2004; Sass, 2008), and even impact its survival, especially for those environmentally-sensitive firms (Pellegrino and Lodhia, 2012). For example, Harbin Pharmaceutical Group, a large drug producer in northeast China, was involved in a pollution scandal for exceeding legal waste gases and water release in 2011, which drew severe criticism from the public and the company was eventually fined 1.23 million yuan $(\$ 191,626)$ by the government and was forced to build a new cleaner production plant. As a result, its revenue and profit dropped by $47.15 \%$ and 
$46.62 \%$, respectively, and it was expelled out of the Top 100 list in 2012.

From a resource-based view, pursuing green innovation requires substantial financial resources, and a corporation's response to external legitimacy pressures depends on its internal resources, among which profitability is of vital importance to green innovation ( $\mathrm{Li}$ and Tang, 2010). Higher profitability would enable a firm to invest in more eco-friendly technologies and management systems (Dean and Brown, 1995).

Legitimacy pressure and corporate profitability are significant external and internal drivers of green innovation (Jennings and Zandbergen, 1995), but few studies have researched their roles simultaneously. Therefore, drawing on insights from institutional theory, resource-based view and innovation literature, this study intends to explore in what ways and how legitimacy pressure and corporate profitability could promote green innovation. Specifically, we argue that green innovation is driven by both external legitimacy pressure and internal corporate profitability, and that profitability positively moderates the relationship between legitimacy pressure and green innovation

The main contributions of this paper are as follows. Firstly, we bridge institutional theory and resource-based view to explore the driving mechanism of green innovation, which is currently under-researched (Berrone, et al., 2013). Secondly, we apply a novel method to measure corporate green innovation through a green patent and ISO14001. We measure green patents with Chinese characters containing "environmental", "green", "sustainable", "ecology", "clean", "cycling", "saving", "low carbon", "emission reduction", "energy saving", "environmental protection", and "environmental pollution" (Cormier and Magnan, 2015). Lastly, we focus on the Chinese context, which is different from most of the research that has come before our study which has been based on the more developed Western countries, and this in turn adds value to theoretical completeness since there are huge differences between developed countries and emerging economies ( $\mathrm{Li}$ and Liu, 2014). 
The remainder of the paper is organized as follows. The next section is the literature review and hypotheses development, followed by sections that outline the research design, methodology, and empirical results. The last section provides a discussion and final conclusion.

\section{Literature review and research hypothesis}

2.1 Legitimacy pressure and green innovation

Legitimacy, first introduced by Weber in 1978, refers to whether an organization's behavior is appropriate within certain social systems (Meyer and Rowan, 1977; Ruef and Scott, 1998; Suchman, 1995). If stakeholders do not approve the activities of an organization, then the organization faces legitimacy pressure. Legitimacy pressure is generally divided into regulatory pressure, normative pressure, and cognitive pressure (DiMaggio and Powell, 2000). For firms, regulatory pressure mainly stems from governmental agencies, while normative pressure is generally from customers and non-governmental organizations, and cognitive pressure is mostly from competitors (Berrone et al, 2013; Li and Ding, 2013).

The choice for opting for cleaner production and green innovation has, at its heart, always been a public goods game ${ }^{1}$ (Perc et al., 2013). There are short-term gains to be made in profit by neglecting the environment, but in the long term, looking specifically at public goods, most notably the environment and natural resources are likely to be lost due to selfish incentives. Such a social dilemma is very common in an agent-based setting where information asymmetry and the selfish incentives of agents lead to the tragedy of the commons (Perc and Szolnoki, 2010). Evolutionary game theory proposes that coevolution with other agents (stakeholders) and the context could help to solve social dilemmas such as climate change (Perc and Szolnoki, 2010). Previous research concluded that an important motivation for corporations adopting green innovative behavior is to get recognized by various stakeholders (Berrone et al, 2013). Delgado-Ceballos et al. (2012) found that

\footnotetext{
1 Thanks for the anonymous reviewer of this insightful suggestion.
} 
stakeholders can affect a company's environmental practices through a variety of channels, including environmental regulations, NGOs' environmental reports, social media supervision, and customers' and suppliers' boycott of non-environmental products. Generally, green innovation becomes an important way for enterprises to cope with external pressures (Berrone et al, 2013). Huang et al. (2016) demonstrated regulatory and customer pressure promotes organizational green innovation performance. The more legitimacy pressure companies receive from stakeholders, the more likely it is they will adopt a green innovation strategy (Murillo-Luna et al, 2008).

Green innovation can be divided into different dimensions or types, among which green process innovation and green product innovation are widely accepted (Chang, 2011; Lin et al., 2014; Rennings and Rammer, 2011; Schiederig et al., 2012).

Green process innovation refers to improvement in the manufacturing processes and systems to reduce the adverse impact on the environment, such as energy saving, pollution prevention, waste recycling, etc. (Qi et al., 2012). With the elevation of environmental consciousness, consumers and environmental protectors start to impose pressure on corporations, who are petitioned to be greener by switching their production and management processes (Bortree, 2009). Delmas and Toffel (2004) and Johnstone and Labonne (2009) also found that pressure from stakeholders will urge corporations to go through the ISO 14001 certification.

Green product innovation involves modifications made to product design, quality and safety, to reduce the impact of the entire product life cycle on the environment, such as the reduction of toxins at production stage, efficient use of energy, and utilizing biodegradable packaging (Kammerer, 2009). The impact of production on the environment can be mainly attributed to the use phase (like fuel consumption and carbon dioxide emissions of cars) and the disposal phase (such as the use of and eventual discarding of heavy metal batteries). In short, green product innovation puts emphasis on the reduction of the impact of manufacturing, use, and disposal on the 
environment (Dangelico and Pontrandolfo, 2010). Chen et al. (2012) found that green product innovation is a strategic response to increasingly stringent environmental requirements raised by multiple stakeholders to ease legitimacy pressure and gain competitive advantage. Thus, we propose:

H1a. Legitimacy pressure is positively correlated with green product innovation H1b. Legitimacy pressure is positively correlated with green process innovation 2.2 Corporate profitability and green innovation

Profitability is an essential resource for firms' future development and an important indicator of managers' autonomy, since a higher level of profitability is a premise for managers to control business operations effectively (Li and Tang, 2010). Corporations with higher profitability would have more funding for green innovation. For example, capital resources enable companies to have the ability to install advanced equipment for pollution prevention, meeting eco-friendly environmental requirements (Dean and Brown, 1995).

According to the resource-based view, internal features like profitability are important determinants of green innovation (Fagerberg et al, 2005). Green innovation requires abundant resources, including funds, labor, material and technology, etc. (Lin et al, 2014). Dangelico and Pujari (2010) posited that investment in green technology is fairly risky due to its resource-consuming nature while exhibiting return-uncertainty. However, companies with higher profitability and sufficient assets are able to afford such expensive investments and pursue it as a differentiation strategy for competitive advantage when competing firms are short of money (Cainelli et al., 2015). In addition, firms with higher profitability could accumulate more liquid assets in direct support of green innovation and commercialization, while lower profitability limits the decision-making power of managers, which may interrupt the continuity of green innovation investments. Thus, we propose:

H2a. Corporate profitability is positively correlated with green product innovation H2b. Corporate profitability is positively correlated with green process innovation 
For companies under legitimacy pressure, higher profitability leads to enough resources to adopt green R\&D activities, to search for new environmental technologies, to employ more eco-friendly production processes, and to produce and promote greener products. When a firm faces higher legitimacy pressure, the contribution of profitability to corporate green innovation is especially important, not only to relieve pressure but also to capture opportunities created by pressure, by tapping into a firm's available resources. However, companies with lower profitability have fewer profits and resources to tap. Even though faced with strong legitimacy pressure, those companies are still unable to make investments in green products development or process improvement in view of limited resources and profits. This is especially true for the "double externality problem" of green innovation; i.e., knowledge spill-over externalities and positive environmental impacts (Rennings, 2000). Thus, we propose:

H3a. Profitability positively moderates the relationship between legitimacy pressure and green product innovation

H3b. Profitability positively moderates the relationship between legitimacy pressure and green process innovation

Fig. 1. below depicts the research model and the hypotheses, showing the influence of legitimacy pressure and corporate profitability on green product innovation and green process innovation.

\section{Fig. 1. Here}

\section{Research design}

\subsection{Samples}

This study selected as its sample an initial 500 observations from the top 100 listed companies of China between 2008 and 2012, as these data are highly continuative, authoritative, and easy to access. The sample selection was conducted as follows: We eliminated two observations that lacked annual reports, and eight 
observations that were listed in the Chinese stock market for less than one year (or their listing was terminated due to excessive earnings management following IPOs), then eliminated three special treatment (ST) observations due to their continuous loss-making over two years. We also eliminated 36 observations with extreme value using the conservative criterion of three standard deviations, 31 observations for companies that issued B-shares and/or $\mathrm{H}$-shares and whose financial characteristics and regulatory environments were different, and another 32 observations whose legitimacy value were zero. As a result, 112 observations were excluded in total, leaving a sample of 388 observations corresponding to 172 different companies.

The research data required were collected primarily from the RESSET database, Baiteng patent network (http://so.5ipatent.com/), and annual reports of all listed companies. Fig. 2. shows the sample distribution by industry. It indicates that Finance and Metals and Mining account for the highest proportion, with 71 and 50 observations, respectively. Leisure and Hospitality is the least represented industry, which only has 8 sampling observations in a five-year range.

\section{Fig. 2. here}

\subsection{Measurements of Variables}

The variables involved in this study are: green innovation, legitimacy pressure, corporate profitability and relevant control variables, such as firm size, ownership and so on. The operational definitions and measuring methods of these variables are described as follows.

\subsubsection{Green innovation}

As discussed above, most research decomposes green innovation into green product innovation and process innovation (Rennings, 2000; Cuerva et al., 2014; Lin et al., 2014). As to green product innovation, there are indicators such as eco-labeling product certification (Lin et al., 2014), green R\&D (Lee and Min, 2015), green patent (Brunnermeier and Cohen, 2003) and so on. Since it is difficult to get the former two 
indicators for Chinese public firms, we employed the last indicator, the green patent, as our indicator of green product innovation (Brunnermeier and Cohen, 2003). We first searched all three kinds of application patents (including patent for invention, patent of utility model and patent of appearance). Then proceeding from the reality of China's economic conditions, green patents of sample observations were selected using the following Chinese keywords: "environmental", "green", "sustainable", "ecology", "clean", "cycling", "saving", "low carbon", "emission reduction", "energy saving", "environmental protection", and "environmental pollution" (Bansal and Clelland, 2004; Cormier and Magnan, 2015). In this study there were 239 observations (about $62 \%$ of the samples) which had no green patents. Therefore, the samples were divided into two categories: 1 for firms with one or more green patents, 0 for no green patent.

As to green process innovation, most research adopts ISO 14001 as its indicator (Chen et al., 2006; Lin et al., 2014), so it was also measured according to whether the corporation passed ISO14001 certification in our study.

\subsubsection{Legitimacy Pressure}

Scholars take public media coverage as an important approach for evaluating environmental legitimacy, which is the most salient and prominent source (Cormier and Magnan, 2015; De Villiers and Van Staden, 2010). For instance, Kuo and Chen (2013) analyzed media coverage about corporate environmental issues by searching and classifying the related articles reported (positive, negative, and neutral). Accordingly, this study applied the extent of media coverage to measure the level of environmental legitimacy, and then took the reciprocal of environmental legitimacy to test legitimacy pressure.

The China Core Newspapers Full-text Database (CCND) is a relatively authoritative database in China, which covers more than 500 national and local newspapers. In this study, 29,794 articles, related to the sample observations, were selected and encoded (positive, neutral, and negative) according to their content. A 
piece of news is coded as positive when it conveys good stories of an enterprise's environmental activities or impacts, such as a reduction in greenhouse gas emissions, investment in facilities which will reduce energy consumption; while negative reports are about firms' environmental misconducts or bad consequences, and neutral ones reflect an activity without assessing any detrimental or beneficial environmental impacts (Aerts and Cormier, 2009; Kuo and Chen, 2013). For example, the report on "BYD Company Limited won an international energy certification" is positive, while the news on "water inrush accident in camel mountain coal mine of China Shenhua" is negative, and "Baotou Steel Rare-earth Group brought 12 enterprises into its overall environmental development plan" is neutral. In order to ensure inter-coder reliability, the evaluation and judgment of articles was performed firstly by one of the authors, then by another evaluator. The two coders agreed on $82 \%$ positive news, $88 \%$ negative news and $93 \%$ neutral news. A third party resolved any differences in the evaluation. Finally, the positive, neutral, and negative judgments of sampled companies, from 2008 to 2012, were found to be 17,188, 10,695, and 1,911, respectively.

Imbalance in the extent of media coverage was examined by calculation with the Janis-Fadner coefficients (Aerts and Cormier, 2009). The value of J-F coefficient ranges from -1 to 1 ; if the value is closer to 1 , the articles are more favorable, and if the value is closer to -1 , the articles are less favorable. It is calculated by the following equation:

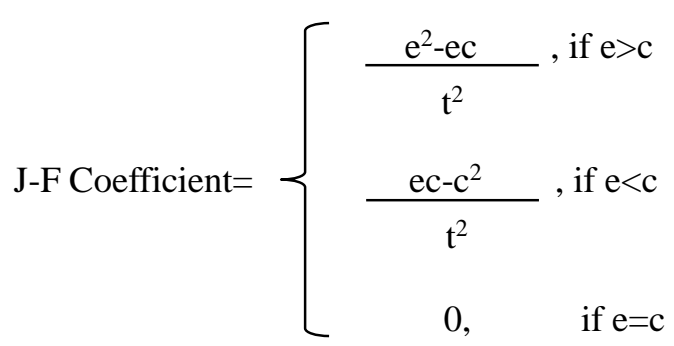

where e represents the number of positive reports, $\mathrm{c}$ represents the number of negative reports, and $\mathrm{t}=\mathrm{e}+\mathrm{c}$. 


\subsubsection{Corporate Profitability}

The higher a company's profitability is, the more inclined the company is to participate in green practices with the support of a large number of resources ( $\mathrm{Li}$ and Tang, 2010). It is measured according to the net profit/total assets (NPTA) ratio.

\subsubsection{Control Variables}

The corporate properties, internal structure, and development level would affect its investment behavior. Accordingly, this study has controlled these seven variables (firm size, ownership, industry type, growth, leverage, leadership structure, and board independence), and their measuring methods are concluded in Table 1.

Table 1 here

\section{Results}

4.1 Descriptive statistics and correlation analysis

Table 2 presents the descriptive statistics and correlations between the variables. It shows that all the correlation coefficients of the matrix are lower than 0.626 , reflecting an acceptable level of multicollinearity (Anderson et al., 2013). However, it is interesting that firm growth is not correlated with any other variables. Although a precise reason is unknown, it is possible that fast growing firms may attract greater positive as well as negative scrutiny than their slower counterparts, showing no clear association with legitimacy. Also, fast growing firms may attach both importance on short-term profitability and long-term green innovation, thus offsetting any association between growth and profitability/green innovation. As to the relationships with other control variables, since growth is about the dynamic development of firms, while others are about the current characteristics, they are not correlated. It is also interesting to note that board independence is only correlated with leadership structure. This may be because that these two variables are both about corporate governance, while the rest are about other aspects of the firm. 
Table 2 here

Table 3 provides the statistics of legitimacy pressure. The positive, neutral, and negative judgments of sampled companies from 2008 to 2012 are 17,188, 10,695, and 1,911, respectively. For example, Suning Commerce Group received high legitimacy on the positive report of “over one hundred billion yuan's green procurement platform emerged in Suning", while Zhongjin Lingnan Nonfemet Company faced high legitimacy pressure on the negative news of "Zhongjin Lingnan was trapped in a pollution scandal".

\section{Table 3 here}

\subsection{The common method bias}

Common method bias,the magnitude of the discrepancies between the observed and the true relationships between constructs, results from common methods variance due to same data sources, measurement of the environment, context of item or characteristics of items themselves (Chang et al., 2010; Podsakoff et al., 2012). If there is a common methods variance, a non rotational factor would be released in the exploratory factor analysis of all the items and the common factor explains most of the variation. One of the most widely used techniques to address the issue of common method bias is Harman's single factor test (Doty \& Glick, 1998), with which researchers load all the variables into an exploratory factor analysis to see whether one single factor does emerge. This method also shows that common method bias is not a pervasive issue if one general factor accounts for a majority of the covariance (Podsakoff et al., 2003; Chang et al., 2010). Because the number of green patents, ISO certification information, and media coverage were all collected manually by the authors, the Harman's single factor test was applied to measure the common method bias. Five factors with eigenvalues greater than 1 were extracted with non-rotating analysis and the cumulative total explanatory variables were $66.155 \%$. The first factor had an eigenvalue of 2.414 and the cumulative total explanatory variables were 
$20.118 \%$, indicating that the common method bias in this study was not severe.

\subsection{Hypothesis testing}

The method of generalized estimating equations (GEE) is often used to analyze longitudinal and other correlated response data, particularly if responses are binary, which derive maximum likelihood estimates and accommodate non-independent observations (Liang and Zeger, 1986; Pan, 2001). Since green product innovation and green process innovation are binary variables, it was suitable to apply the generalized estimating equations (GEE) approach to test the hypotheses.

\subsubsection{The role of legitimacy pressure}

This part tested the effect of legitimacy pressure on green innovation. As shown in Table 4, Model 1 and Model 5 are the relationships among control variables and the dependent variable. Model 2 and Model 6 introduce the independent variables. Model 2 demonstrates that legitimacy pressure is significantly positively correlated with green product innovation $(\beta=0.250, \mathrm{p}<0.05)$, and Model 6 shows that legitimacy pressure is significantly positively correlated with green process innovation $(\beta=$ 0.364, $\mathrm{p}<0.01)$. Therefore, both H1a and H1b were supported. This suggested that the higher a company's legitimacy pressure is, the higher its level of green innovation will be. For example, Baotou Steel Rare-earth Group was accused of "failing to complete the environmental impact assessment" in 2012. As a result, under the high legitimacy pressure, the green patent number of the firm rose from 0 in 2011 to 3 in 2012.

\subsubsection{The role of corporate profitability}

This section tested the effect of corporate profitability on green innovation. As shown in Table 4, Model 3 shows that profitability is significantly positively correlated with green product innovation $(\beta=0.513, \mathrm{p}<0.1)$, and Model 7 indicates the effect of profitability on green process innovation is not evident $(\beta=0.022, \mathrm{p}>$ 0.1). Therefore, H2a was supported, while $\mathrm{H} 2 \mathrm{~b}$ was not supported. This suggested that companies with nice profitability are more likely to invest in green product 
innovation.

This section also tested the moderating effect of profitability on the relationship of legitimacy pressure and green innovation. Model 3 indicated that legitimacy pressure was still significantly positively correlated with green product innovation ( $\beta$ $=0.238, \mathrm{p}<0.05)$, as corporate profitability is introduced. Model 4 was generated based on Model 3 by introducing the interactive item of legitimacy pressure and corporate profitability. The results indicated that profitability has a moderating effect on the relationship between legitimacy pressure and green product innovation $(\beta=$ 1.411, $\mathrm{p}<0.05)$. Moreover, Model 7 showed that legitimacy pressure was still significantly positively correlated with green process innovation $(\beta=0.284, p<0.01)$ as corporate profitability is introduced. Model 8 was generated based on Model 7 by introducing the interactive item of legitimacy pressure and corporate profitability. The results indicated that profitability has no moderating effect on the relationship between legitimacy pressure and green process innovation $(\beta=0.058, \mathrm{p}>0.1)$. Therefore, H3a was supported, while $\mathrm{H} 3 \mathrm{~b}$ was not supported, showing that profitability has a moderating effect on the relationship between legitimacy pressure and green product innovation.

\section{Table 4 here}

\section{Discussion and Conclusions}

This study analyzed the impact of both external legitimacy pressure and internal corporate profitability, on green innovation, by considering the moderating role of profitability. Using a sample of 388 observations, obtained from the top 100 listed companies of China from 2008 to 2012, we found that legitimacy pressure was significantly positively correlated with both green product innovation and green process innovation, and that profitability had a significantly positive impact on green product innovation, while its effect on green process innovation was not significant. 
Moreover, corporate profitability positively moderated the relationship between legitimacy pressure and green product innovation, while its moderating effect on the relationship between legitimacy pressure and green process innovation was not evident. The scientific value added is, that a novel framework integrating not only is the single driving factor of external legitimacy pressure and internal corporate profitability, but also their interaction has a strong effect on green innovation. The main findings of this study are as follows:

First, legitimacy pressure is positively correlated with both green product innovation and green process innovation. This result is in line with the findings of Amores-Salvadó et al. (2014) instead of those of Dangelico and Pujari (2010). Dangelico and Pujari (2010) found that green product innovation is not driven by external legitimacy pressure, but by internal factors such as green market expectations, increasing profits, improving corporate image, environmental orientation of firms or executives and so on. Amores-Salvadó et al. (2014) suggested that legitimacy pressure will encourage enterprises to increase green product innovation to cope with legitimacy pressure and satisfy public expectations. The latter findings, which are in accordance with the findings of Sezen and Çankaya (2013), showed that companies will increase green process innovation under legitimacy pressure. The reason for this may be that, since environmental legitimacy is becoming increasingly important in the pollution era, corporations have to find effective ways to cope with stakeholders' pressure, among which green patent application and environmental management systems are regarded as substantive methods not only to deal with short-time external pressures, but also to gain competitive advantage in the long run. For instance, Zijin Mining, the largest gold producer in China, was accused by the public of leaking acidic wastewater, infused with copper, into local water sources, which caused severe pollution to the local river in 2010 . The pressure forced the corporation to adopt an environmental management system and they finally received the certification in 2012 . Moreover, the green patent of the firm nearly doubled, increasing from six in 2009 to 
eleven in 2010.

Second, to our surprise, profitability is significantly positively related to green product innovation $(\beta=0.513, \mathrm{p}<0.1)$ while not significant related to green process innovation $(\beta=0.022, \mathrm{p}>0.1)$. The reasons may be that, on the one hand, green product innovation does not need as much investment as green process innovation, which requires systematic improvement of the whole operational and managerial process. On the other hand, the outcome of green product innovation and green patents, can be directly adopted into the production of new products or be sold in the market, and thus be easily translated into technological advantage and revenue, while the implementation of green process innovation is time consuming and the effects are not so direct and evident. So, Chinese firms tend to invest their profitability in green product innovation rather than process innovation. For example, China State Construction Engineering Corporation witnessed a 28.29\% increase of profit in 2012. Consequently, its green patent rose from 28 in 2011 to 32 in 2012, but without implementing an environmental management system.

Thirdly, profitability plays a significantly positive moderating role between legitimacy pressure and green product innovation, while no moderating effect is found between the relationship of legitimacy pressure and green process innovation. The former result means that, faced with legitimacy pressure, companies with higher profitability maintain sufficient liquid resources to support green product innovation to promote sustainable development through developing environmentally friendly patents and products. The latter results indicate that when facing legitimacy pressure, firms will adopt a certain amount of green process innovation regardless of the level of corporate profitability.

The findings above have several practical implications. Firstly, since legitimacy pressure directly affects corporate green innovation, companies should meet the environmental requirements of stakeholders to enhance external legitimacy. Secondly, companies should improve profitability to obtain more resources to support the 
research and development of clean energy and to invest in cleaner cycling production methods, and environmental management systems to facilitate green innovation, and sustainable development. Thirdly, as to the current low levels of green product innovation (62\% of the samples with no green patents), the intensity of green product innovation should be enhanced. Last, but not least, the role of green process innovation is widely acknowledged by current literature (King, Lenox, and Terlaak, 2005). Firms should not only invest in green product innovation but also green process innovation, which is largely ignored by many firms (54\% of the samples with no ISO 14001 certification).

However, there are also some limitations. Firstly, though we tried to conduct research into the drivers of green innovation from both external and internal perspectives, we only investigated legitimacy pressure and corporate profitability, with many other variables which may affect the relationship omitted, such as industrial competition, firms' intellectual capital and so on. Secondly, we only focused on the Chinese top 100 listed companies, so the findings may be applicable to large corporations in emerging economies, but may not be applicable to smaller firms or developed countries' firms. Future studies should focus on other firms, within different scales and different countries, and establish a comparison with the findings of this study.

\section{Acknowledgments}

This work is supported by the National Natural Science Foundation of China (Grant No.71202055; 71372064; 71431006), Major project of National Social Sciences Fund of China (Grant No. 15ZDA020), Innovative Research Group National Science Foundation of China (Grant No.71221061), and Key Projects of Philosophy and Social Sciences Research of Ministry of Education of China (Grant No.13jzd0016). The authors thank the Editors and referees for their helpful comments and suggestions. 


\section{References}

Aerts, W., \& Cormier, D., 2009. Media legitimacy and corporate environmental communication. Acc. org. Socie. 34(1), 1-27.

Alrazi, B., de Villiers, C., van Staden, C. J., 2015. A comprehensive literature review on, and the construction of a framework for, environmental legitimacy, accountability and proactivity. J. Clean. Prod. 102, 44-57.

Amores-Salvadó, J., Martín-de Castro, G., Navas-López, J. E., 2014. Green corporate image: moderating the connection between environmental product innovation and firm performance. J. Clean. Prod. 83, 356-365.

Arimura, T., Hibiki, A., Johnstone, N., 2007. An empirical study of environmental RD: what encourages facilities to be environmentally innovative. Environ. Policy Corp. Behav. 142-173.

Bansal, P., Clelland, I., 2004. Talking trash: Legitimacy, impression management, and unsystematic risk in the context of the natural environment. Acad. Manag. J. 47(1), 93-103.

Bernauer, T., Engel, S., Kammerer, D., Sejas Nogareda, J., 2007. Explaining green innovation: ten years after porter's win-win proposition: how to study the effects of regulation on corporate environmental innovation?. Politische Vierteljahresschrift. 39, 323-341.

Berrone, P., Fosfuri, A., Gelabert, L., Gomez-Mejia, L. R., 2013. Necessity as the mother of 'green'inventions: Institutional pressures and environmental innovations. Strateg. Manag. J. 34(8), 891-909.

Bitektine, A., 2011. Toward a theory of social judgments of organizations: The case of legitimacy, reputation, and status. Acad. Manag. Rev..36(1), 151-179.

Bortree, D. S., 2009. The impact of green initiatives on environmental legitimacy and admiration of the organization. Publi. Relat. Rev. 35(2), 133-135.

Brunnermeier, S. B., Cohen, M. A., 2003. Determinants of environmental innovation in US manufacturing industries. J. Environ. Econ. Manag. 45(2), 278-293.

Cainelli, G., De Marchi, V., Grandinetti, R., 2015. Does the development of environmental innovation require different resources? Evidence from Spanish manufacturing firms. J. Clean. Prod. 94, 211-220.

Caputo, M. R., 2014. Comparative statics of a monopolistic firm facing price-cap and command-and-control environmental regulations. Energ. Econ. 46, 464-471.

Chang, C. H., 2011. The influence of corporate environmental ethics on 
competitive advantage: the mediation role of green innovation. J. Bus. Ethics. 104(3), 361-370.

Chang, S. J., Van Witteloostuijn, A., Eden, L., 2010. From the editors: Common method variance in international business research. J. Int. Bus. Stud. 41(2), 178-184.

Chen, Y. S., Chang, C. H., Wu, F. S., 2012. Origins of green innovations: the differences between proactive and reactive green innovations. Manag. Deci. 50(3), 368-398.

Chen, Y. S., Lai, S. B., Wen, C. T., 2006. The influence of green innovation performance on corporate advantage in Taiwan. J. Bus. Ethics. 67(4), 331-339.

Cormier, D., Magnan, M., 2015. The economic relevance of environmental disclosure and its impact on corporate legitimacy: An empirical investigation. Bus. Strateg. Environ. 24(6), 431-450.

Costantini, V., Mazzanti, M., 2012. On the green and innovative side of trade competitiveness? The impact of environmental policies and innovation on EU exports. Res. Policy. 41(1), 132-153.

Cuerva, M. C., Triguero-Cano, Á., Córcoles, D., 2014. Drivers of green and non-green innovation: empirical evidence in Low-Tech SMEs. J. Clean. Prod. 68, 104-113.

Dangelico, R. M., Pontrandolfo, P., 2010. From green product definitions and classifications to the Green Option Matrix. J. Clean. Prod. 18(16), 1608-1628.

Dangelico, R. M., Pujari, D., 2010. Mainstreaming green product innovation: Why and how companies integrate environmental sustainability. J. Bus. Ethics. 95(3), 471-486.

Dean, T. J., Brown, R. L., 1995. Pollution regulation as a barrier to new firm entry: Initial evidence and implications for future research. Acad. Manag. J. 38(1), 288-303.

Delmas, M., Toffel, M. W., 2004. Stakeholders and environmental management practices: an institutional framework. Bus. Strateg. Environ. 13(4), 209-222.

Delgado-Ceballos, J., Aragón-Correa, J. A., Ortiz-de-Mandojana, N., Rueda-Manzanares, A., 2012. The effect of internal barriers on the connection between stakeholder integration and proactive environmental strategies. J. Bus. Ethics. 107(3), 281-293.

De Marchi, V, 2012. Environmental innovation and RD cooperation: Empirical evidence from Spanish manufacturing firms. Res. Policy. 41(3), 614-623. 
DiMaggio, P. J., Powell, W. W., 2000. The iron cage revisited-Institutional isomorphism and collective rationality in organizational fields. Adv. Strateg. Manag. 17, 143-166.

Doty, D. H., Glick, W. H., 1998. Common methods bias: does common methods variance really bias results?. Org. Res. Methods,1(4), 374-406.

Eiadat, Y., Kelly, A., Roche, F., Eyadat, H., 2008. Green and competitive? An empirical test of the mediating role of environmental innovation strategy. J. World Bus. 43(2), 131-145.

Fagerberg, J., Godinho, M., M., 2005. Innovation and catching-up. The Oxford Handbook of Innovation. Oxford University Press, New York. 514-543.

Frondel, M., Horbach, J., Rennings, K., 2007. End-of-pipe or cleaner production? An empirical comparison of environmental innovation decisions across OECD countries. Bus. Strateg. Environ. 16(8), 571-584.

Grewal, R., Dharwadkar, R., 2002. The role of the institutional environment in marketing channels. J. Market. 66(3), 82-97.

Guoyou, Q., Saixing, Z., Chiming, T., Haitao, Y., Hailiang, Z., 2013. Stakeholders' influences on corporate green innovation strategy: a case study of manufacturing firms in China. Corp. Soc. Respon. Environ. Manag. 20(1), 1-14.

Horbach, J., 2008. Determinants of environmental innovation-new evidence from German panel data sources. Res. Policy. 37(1), 163-173.

Horváthová, E., 2012. The impact of environmental performance on firm performance: Short-term costs and long-term benefits? Ecol. Econ.. 84, 91-97.

Huang, X. X., Hu, Z. P., Liu, C. S., Yu, D. J., Yu, L. F., 2016. The relationships between regulatory and customer pressure, green organizational responses, and green innovation performance. J. Clean. Prod. 112, 3423-3433.

Huang, Y. C., Ding, H. B., Kao, M. R., 2009. Salient stakeholder voices: Family business and green innovation adoption. J. Manag. Org. 15(3), 309-326.

Hart, S. L., 1995. A natural-resource-based view of the firm. Acad. Manag. Rev. 20(4), 986-1014.

Jennings, P. D., Zandbergen, P. A., 1995. Ecologically sustainable organizations: An institutional approach. Acad. Manag. Rev. 20(4), 1015-1052.

Johnson T., 2011. Environmental information disclosure in China: Policy developments and NGO responses. Policy Politics. 39(3): 399-416.

Johnstone, N., Labonne, J., 2009. Why do manufacturing facilities introduce 
environmental management systems? Improving and/or signaling performance. Ecol. Econ. 68(3), 719-730.

Kammerer, D., 2009. The effects of customer benefit and regulation on environmental product innovation: empirical evidence from appliance manufacturers in Germany. Ecol. Econ.. 68(8), 2285-2295.

Kemp, R., Pearson, P., 2007. Final report MEI project about measuring eco-innovation. UM Merit, Maastricht. 10.

King, A. A., Lenox, M. J., Terlaak, A., 2005. The strategic use of decentralized institutions: Exploring certification with the ISO 14001 management standard. Acad. Manag. J. 48(6), 1091-1106.

Kuo, L., Chen, Y. V., 2013. Is environmental disclosure an effective strategy on establishment of environmental legitimacy for organization? Manag. Deci. 51(7), 1462-1487.

Lai, S. B., Wen, C. T., Chen, Y. S., 2003. The exploration of the relationship between the environmental pressure and the corporate competitive advantage. In 2003 CSMOT Academic Conference (National Chiao Tung University, Hsin-Chu).

Lee, K. H., Min, B., 2015. Green R\&D for eco-innovation and its impact on carbon emissions and firm performance. J. Clean. Prod. 108, 534-542.

Li, D. Y., Liu, J., 2014. Dynamic capabilities, environmental dynamism, and competitive advantage: Evidence from China. J. Bus. Res. 67(1), 2793-2799.

Li, F., Ding, D. Z., 2013. The effect of institutional isomorphic pressure on the internationalization of firms in an emerging economy: evidence from China. Asia Pacific. Bus. Rev. 19(4), 506-525.

Li, J., Tang, Y. I., 2010. CEO hubris and firm risk taking in China: The moderating role of managerial discretion. Acad. Manag. J. 53(1), 45-68.

Liang, K. Y., Zeger, S. L., 1986. Longitudinal data analysis using generalized linear models. Biometrika. 73(1), 13-22.

Lin, H., Zeng, S. X., Ma, H. Y., Qi, G. Y., Tam, V. W., 2014. Can political capital drive corporate green innovation? Lessons from China. J. Clean. Prod. 64, 63-72.

Lozano, R., 2015. A holistic perspective on corporate sustainability drivers. Corp. Soc. Resp. Env. Manag. 22(1), 32-44.

Meyer, J. W., Rowan, B., 1977. Institutionalized organizations: Formal structure as myth and ceremony. Am. J. Soc. 340-363.

Murillo-Luna, J. L., Garcés-Ayerbe, C., Rivera-Torres, P., 2008. Why do patterns 
of environmental response differ? A stakeholders' pressure approach. Strateg. Manag. J. 29(11), 1225-1240.

Nishitani, K., 2009. An empirical study of the initial adoption of ISO 14001 in Japanese manufacturing firms. Ecol. Econ.. 68(3), 669-679.

Orlitzky, M., Schmidt, F. L., Rynes, S. L., 2003. Corporate social and financial performance: A meta-analysis. Org. Studies. 24(3), 403-441.

Pan, W., 2001. Akaike's information criterion in generalized estimating equations. Biometrics. 57(1): 120-125.

Pellegrino, C., Lodhia, S., 2012. Climate change accounting and the Australian mining industry: exploring the links between corporate disclosure and the generation of legitimacy. J. Clean. Prod. 36, 68-82.

Perc, M., Szolnoki, A., 2010. Coevolutionary games-a mini review. BioSystems, 99(2): 109-125.

Perc, M., Gómez-Gardeñes, J., Szolnoki, A., Floría, L. M., Moreno, Y., 2013. Evolutionary dynamics of group interactions on structured populations: a review. J. R. Soc. Interface. 10(80), 20120997.

Podsakoff, P. M., MacKenzie, S. B., Lee, J. Y., Podsakoff, N. P., 2003. Common method biases in behavioral research: a critical review of the literature and recommended remedies. J. Appl. Psychol. 88(5), 879.

Podsakoff, P. M., MacKenzie, S. B., Podsakoff, N. P., 2012. Sources of method bias in social science research and recommendations on how to control it. Annu. Rev. Psychol. 63, 539-569.

Porter, M. E., Kramer, M. R., 2002. The competitive advantage of corporate philanthropy. Harv. Bus. Rev. 80(12), 56-68.

Qi, G., Zeng, S., Li, X., Tam, C., 2012. Role of internalization process in defining the relationship between ISO 14001 certification and corporate environmental performance. Corp. Soc. Respon. Environ. Manag. 19(3), 129-140.

Rehfeld, K. M., Rennings, K., Ziegler, A., 2007. Integrated product policy and environmental product innovations: An empirical analysis. Ecol. Econ. 61(1), 91-100.

Rennings, K., 2000. Redefining innovation-eco-innovation research and the contribution from ecological economics. Ecol. Econ. 32(2), 319-332.

Rennings, K., Rammer, C., 2011. The impact of regulation-driven environmental innovation on innovation success and firm performance. Ind. Innov. 18(3), 255-283.

Rennings, K., Zwick, T., 2002. Employment impact of cleaner production on the 
firm level: Empirical evidence from a survey in five European countries. International J. Innov. Manag. 6(3), 319-342.

Ruef, M., Scott, W. R., 1998. A multidimensional model of organizational legitimacy: Hospital survival in changing institutional environments. Adm. Sci. Quart. 877-904.

Sarkis, J., Cordeiro, J. J., 2001. An empirical evaluation of environmental efficiencies and firm performance: pollution prevention versus end-of-pipe practice. Europ. J. Opera. Res. 135(1), 102-113.

Sass, E, 2008. Consumers consider sustainability in choosing brands. MediaPost, available at: http://publications. mediapost. com/index. Cfm.

Schiederig, T., Tietze, F., Herstatt, C., 2012. Green innovation in technology and innovation management-an exploratory literature Rev. RD Manag. 42(2), 180-192.

Sezen, B., Cankaya, S. Y., 2013. Effects of green manufacturing and eco-innovation on sustainability performance. Procedia-Soc. Behav. Sci. 99, 154-163.

Suchman, M. C., 1995. Managing legitimacy: Strategic and institutional approaches. Acad. Manag. Rev. 20(3), 571-610.

Tan Y., 2014. Transparency without democracy: the unexpected effects of China's environmental disclosure policy. Governance. 27(1), 37-62. 


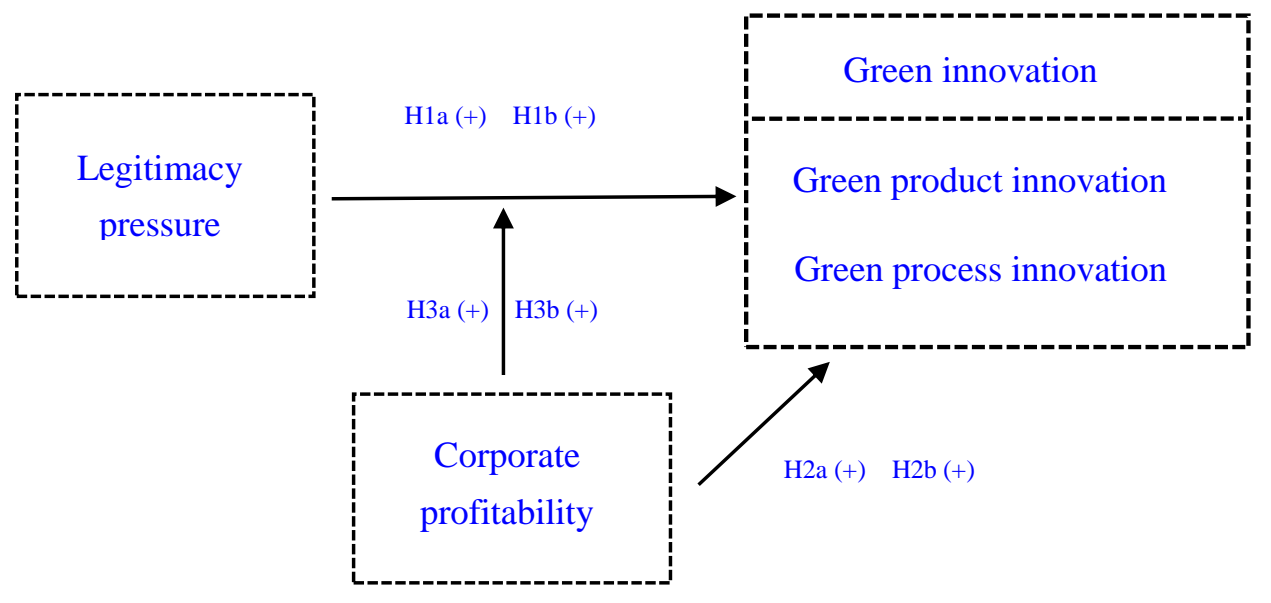

Fig. 1. Research model.

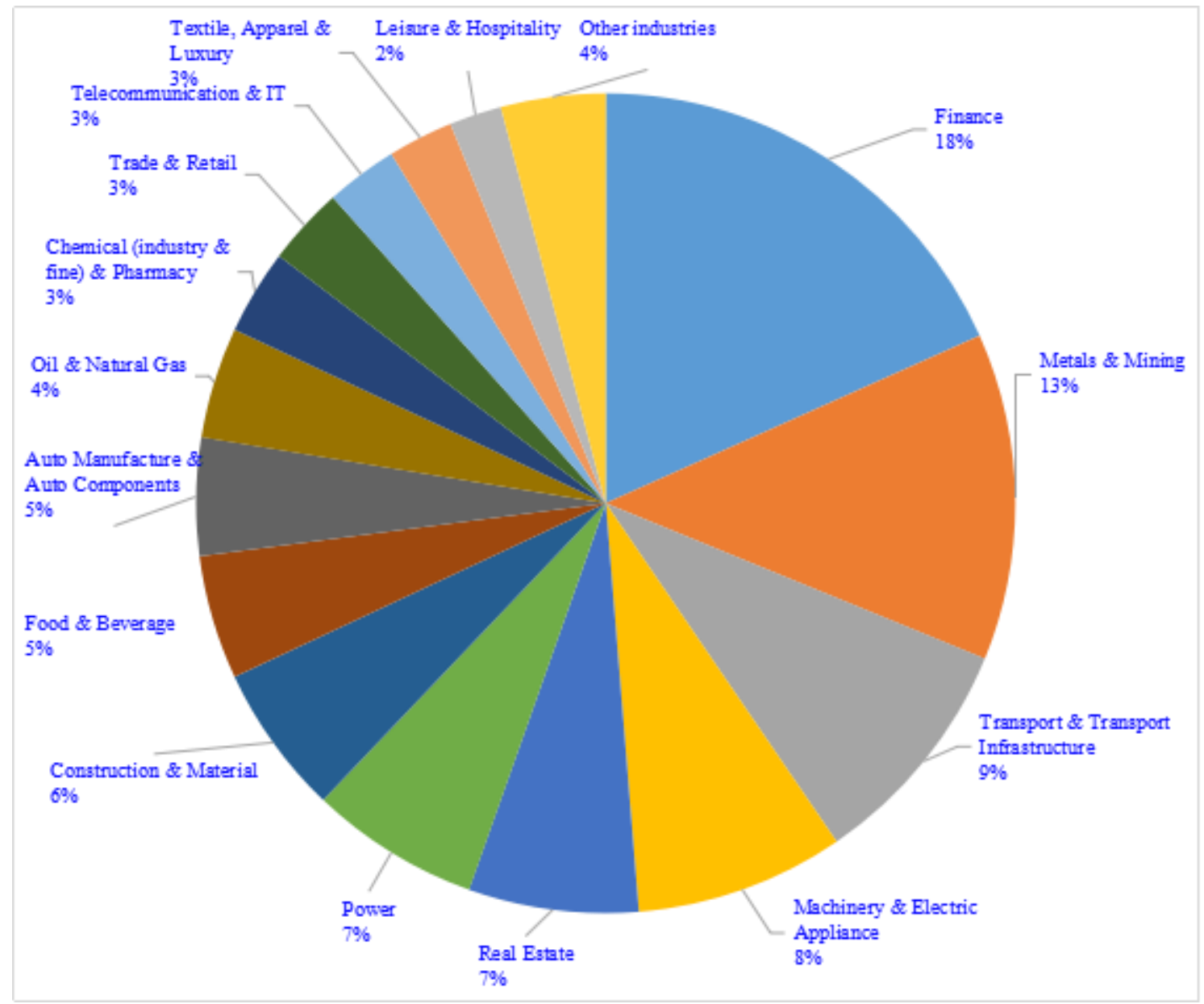

Note: "Other industries" include paper and forestry products, public utilities, and durable consumer goods; $\mathrm{N}=388$.

Fig.2. Sample distribution of total observations by industry. 
Table 1

Measurements of control variables used in this research.

\begin{tabular}{|c|c|c|}
\hline Variables & Symbols & Measuring Methods \\
\hline Firm Size & size & $\begin{array}{l}\text { The logarithm of total assets was employed to measure firm } \\
\text { size. }\end{array}$ \\
\hline Ownership & Own & $\begin{array}{l}\text { A dummy variable was thus introduced here, } 1 \text { for state-owned } \\
\text { enterprises (SOEs), } 0 \text { for others. }\end{array}$ \\
\hline Industry Type & Ind & $\begin{array}{l}\text { According to the "Company Environmental Information } \\
\text { Disclosure Guide", a zero-one dummy variable was used: } 1 \text { for } \\
\text { heavily polluting industries, } 0 \text { otherwise. }\end{array}$ \\
\hline Growth & Gro & $\begin{array}{l}\text { It is measured by the ratio of (current POR- previous POR) } \\
\text { /previous POR ("POR" refers to prime operating revenue). }\end{array}$ \\
\hline Leverage & Lev & $\begin{array}{l}\text { The ratio EBIT/ (EBIT - Interest expense) was used for } \\
\text { measurement (where "EBIT" refers to earnings before interest). }\end{array}$ \\
\hline $\begin{array}{l}\text { Leadership } \\
\text { Structure }\end{array}$ & LS & $\begin{array}{l}\text { A dummy variable was introduced: } 1 \text { refers to a company } \\
\text { whose chief executive officer (CEO) is not the chairperson of } \\
\text { the board (COB), } 0 \text { otherwise. }\end{array}$ \\
\hline $\begin{array}{l}\text { Board } \\
\text { Independence }\end{array}$ & Indep & $\begin{array}{l}\text { The independent directors/board size ratio was used for } \\
\text { measurement }\end{array}$ \\
\hline
\end{tabular}

Table 2

Descriptive statistics and correlation matrix: dependent and explanatory variables.

\begin{tabular}{|c|c|c|c|c|c|c|c|c|c|c|c|c|}
\hline & Min & $\operatorname{Max}$ & GPDI & GPCI & LP & Pro & Size & Own & Ind & Gro & Lev & LS \\
\hline GPDI & 0.000 & 1.000 & & & & & & & & & & \\
\hline GPCI & 0.000 & 1.000 & -0.054 & & & & & & & & & \\
\hline LP & -64.058 & 56.067 & $0.251 * * *$ & $0.110^{* *}$ & & & & & & & & \\
\hline Pro & -0.199 & 0.581 & $0.129 * *$ & 0.100 & 0.052 & & & & & & & \\
\hline Size & 9.361 & 13.244 & 0.000 & $-0.202 * * *$ & 0.031 & $-0.390 * * *$ & & & & & & \\
\hline Own & 0.000 & 1.000 & 0.021 & $-0.094 *$ & -0.014 & $-0.168 * * *$ & $0.156 * * *$ & & & & & \\
\hline Ind & 0.000 & 1.000 & $0.335^{* * *}$ & 0.041 & $-0.092 *$ & 0.052 & $-0.144 * * *$ & $0.123 * *$ & & & & \\
\hline Gro & -0.877 & 3.688 & -0.046 & -0.007 & 0.049 & 0.049 & -0.017 & -0.039 & -0.014 & & & \\
\hline Lev & -16.062 & 28.810 & $-0.193 * * *$ & -0.044 & -0.022 & $-0.314 * * *$ & $0.626 * * *$ & -0.025 & $-0.256 * * *$ & 0.033 & & \\
\hline LS & 0.000 & 1.000 & -0.041 & $0.103 * *$ & 0.036 & $-0.175^{* * *}$ & $0.169 * * *$ & 0.062 & 0.046 & 0.000 & $0.118 * *$ & \\
\hline Indep & 0.714 & 3.363 & 0.001 & -0.008 & 0.017 & -0.021 & -0.037 & 0.042 & 0.056 & 0.024 & -0.064 & $-0.205^{*} * *$ \\
\hline
\end{tabular}

Notes: $* * * \mathrm{p}<1 \%, * * \mathrm{p}<5 \%, * \mathrm{p}<10 \%$. Two-tailed. $\mathrm{N}=388$. 


\section{Table 3}

The environmental legitimacy scores of sampled companies from 2008 to 2012.

\begin{tabular}{cccccccc}
\hline & \multicolumn{7}{c}{ Year } \\
\cline { 2 - 6 } Judgment & 2008 & 2009 & 2010 & 2011 & 2012 & Total & Percentage \\
\hline Positive & 4011 & 4321 & 3518 & 2779 & 2559 & 17188 & 0.5769 \\
Neutral & 1166 & 1763 & 2358 & 2561 & 2847 & 10695 & 0.3590 \\
Negative & 454 & 304 & 408 & 379 & 366 & 1911 & 0.0641 \\
Total & 5631 & 6388 & 6284 & 5719 & 5772 & 29794 & 1 \\
\hline
\end{tabular}

\section{Table 4}

Results of generalized estimating equations on green product innovation and green process innovation.

\begin{tabular}{|c|c|c|c|c|}
\hline \multicolumn{5}{|c|}{ Generalized Estimating Equations } \\
\hline \multirow{2}{*}{ Dependent Variables } & \multicolumn{4}{|c|}{ Green Product Innovation } \\
\hline & Model 1 & Model 2 & Model 3 & Model 4 \\
\hline \multicolumn{5}{|l|}{ 1.Control Variables } \\
\hline Size & $-0.068(0.081)$ & $-0.004(0.000)$ & $0.130(0.640)$ & $0.149(0.833)$ \\
\hline Ownership & $-0.516(2.708)$ & $-0.482(1.294)$ & $-0.431(0.894)$ & $-0.437(0.763)$ \\
\hline Industry & $-0.795 *(3.316)$ & $-0.792 *(3.210)$ & $-0.725 * *(4.280)$ & $-0.694 * *(3.759)$ \\
\hline Growth & $0.001(0.000)$ & $0.011(0.004)$ & $0.065(0.141)$ & $0.069(0.150)$ \\
\hline Leverage & $-0.120(0.231)$ & $-0.196(0.337)$ & $-0.454(1.673)$ & $-0.472(1.832)$ \\
\hline Leadership Structure & $-0.085(0.019)$ & $-0.043(0.006)$ & $0.222(0.097)$ & $0.228(0.104)$ \\
\hline Independence & $-0.127 * *(4.033)$ & $-0.139 *(3.029)$ & $-0.175 *(3.520)$ & $-0.183 *(3.352)$ \\
\hline \multicolumn{5}{|c|}{ 2.Independent Variable \& Moderating Variable } \\
\hline Legitimacy Pressure & & $0.250 * *(4.079)$ & $0.238 * *(3.779)$ & $0.191 * *(4.015)$ \\
\hline Profitability & & & $0.513 *(3.066)$ & $0.522 *(3.352)$ \\
\hline \multicolumn{5}{|l|}{ 3. Moderating Effect } \\
\hline LP*Pro & & & & $1.411 * *(4.292)$ \\
\hline
\end{tabular}

\begin{tabular}{lllll}
\hline \multirow{2}{*}{ Dependent Variables } & \multicolumn{4}{c}{ Green Process Innovation } \\
\cline { 2 - 5 } & Model 5 & Model 6 & Model 7 & Model 8 \\
\hline 1.Control Variables & & & & \\
Size & $0.039(0.014)$ & $0.054(0.025)$ & $0.083(0.053)$ & $0.163(0.205)$ \\
Ownership & $-0.003(0.000)$ & $-0.241(0.113)$ & $0.291(0.328)$ & $0.348(0.750)$ \\
Industry & $0.610 *(2.625)$ & $0.567(1.972)$ & $-0.581(1.642)$ & $-0.603(1.588)$ \\
Growth & $-0.008(0.004)$ & $0.008(0.003)$ & $0.065(0.185)$ & $0.100(0.400)$
\end{tabular}




\begin{tabular}{|c|c|c|c|c|}
\hline Leverage & $0.871 *(3.176)$ & $0.718(2.155)$ & $-1.005 *(3.511)$ & $-1.140 * *(4.263)$ \\
\hline Leadership Structure & $0.272(0.558)$ & $0.227(0.329)$ & $-0.380(0.887)$ & $-0.414(1.035)$ \\
\hline Independence & $0.355(1.044)$ & $0.435(1.036)$ & $-0.565(1.632)$ & $-0.570(1.733)$ \\
\hline \multicolumn{5}{|c|}{ 2.Independent Variable \& Moderating Variable } \\
\hline Legitimacy Pressure & & $0.364 * * *(6.224)$ & $0.284 * * *(6.676)$ & $0.060(0.112)$ \\
\hline Profitability & & & $0.022(0.015)$ & $0.056(0.102)$ \\
\hline \multicolumn{5}{|l|}{ 3. Moderating Effect } \\
\hline LP*Pro & & & & $0.058(0.048)$ \\
\hline
\end{tabular}

Notes: $* * * \mathrm{p}<1 \%, * * \mathrm{p}<5 \%,{ }^{*} \mathrm{p}<10 \%$. Two-tailed. $\mathrm{N}=388$. 